\title{
Carbon, nitrogen and phosphorus processing by an oyster reef
}

\author{
Richard F. Dame ${ }^{1}$, John D. Spurrier ${ }^{2}$, Thomas G. Wolaver ${ }^{3}$ \\ ${ }^{1}$ Coastal Carolina College of the University of South Carolina, Conway, South Carolina 29526, USA \\ ${ }^{2}$ Department of Statistics, University of South Carolina, Columbia, South Carolina 29208, USA \\ ${ }^{3}$ Belle W. Baruch Institute for Marine Biology and Coastal Research, Georgetown, South Carolina 29442, USA
}

\begin{abstract}
Simultaneous annual fluxes of carbon, nitrogen and phosphorus were studied on an intertidal oyster reef in Bly Creek, South Carolina, USA. We observed material fluxes every 10.2 d (33 tidal cycles) over 1 yr and used regression estimation to compute annual estimates. The reef appeared to take up $1200 \mathrm{~g} \mathrm{C} \mathrm{m}^{-2} \mathrm{yr}^{-1}$ from tidal waters. It had an estimated net removal of $189 \mathrm{~g} \mathrm{~N} \mathrm{~m}^{-2} \mathrm{yr}^{-1}$ from the water column with the majority of this nitrogen released as ammonium $\left(125 \mathrm{~g} \mathrm{~N} \mathrm{~m}^{-2} \mathrm{yr}^{-1}\right)$, and a net uptake of $98 \mathrm{~g} \mathrm{P} \mathrm{m}^{-2} \mathrm{yr}^{-1}$. As indicated by the $\mathrm{C}: \mathrm{N}: \mathrm{P}$ ratio of the fluxes, proportionally more phosphorus was taken up than would be expected. Oyster reefs process carbon, nitrogen und phosphorus at high rates and appear to function as retention mechanisms for nitrogen and phosphorus in estuaries.
\end{abstract}

\section{INTRODUCTION}

Bivalve filter feeders in marsh-estuarine systems may increase sedimentation (Verwey 1952, Haven \& Morales-Alamo 1966, Dame et al. 1980, Doering et al. 1986), act to retain essential nutrients (Kuenzler 1961, Jordan \& Valiela 1982, Bertness 1984), control water column microbial biomass through filtration (Dame et al. 1980, Cloern 1982, Officer et al. 1982, Wright et al. 1982, Nichols 1985), increase benthic remineralization rates (Dame et al. 1985, Murphy \& Kremer 1985, Doering et al. 1986), increase benthic respiration (Murphy \& Kremer 1985), increase system production (Doering et al. 1986) and increase system recycling of materials (Dame et al. 1985, Doering et al. 1986). In spite of these implications, there have been few direct estimates with an assessment of statistical variability for material exchanges between natural bivalve systems and the overlaying water column and none simultaneously observing carbon, nitrogen and phosphorus fluxes.

Kitchell et al. (1979) noted that consumer organisms may control the rates of nutrient cycling in ecosystems by translocating and transforming matter. Dense filter feeder systems such as oyster reefs translocate materials by removing suspended matter from the water column and depositing this material on the bottom. Also, filter feeders transform suspended material by changing particle size distributions in the water column and converting particulate materials into dissolved constituents or biomass via metabolism (Dame et al. 1980). Preliminary observations by Dame et al. $(1984,1985)$ indicated that under summer conditions oyster reefs are removing particulate material and releasing ammonium. This study focuses on the seasonal and annual processing of carbon, nitrogen and phosphorus by an oyster reef within the intensively studied North Inlet, South Carolina marsh-estuarine system (see Dame et al. 1986 for a review).

\section{METHODS}

We selected an intertidal oyster reef dominated by the American oyster Crassostrea virginica for this study. The reef covers $600 \mathrm{~m}^{2}$ within the intensively studied Bly Creek drainage basin which is part of the North Inlet estuary near Georgetown, South Carolina. Water temperatures vary seasonally from 8 to $30^{\circ} \mathrm{C}$ and salinity varies from 15 to $35 \mathrm{ppt}$ with depressed salinities common during late winter.

In order to determine the uptake and release rates of carbon, nitrogen and phosphorus from a benthic system, the amount of water flowing over the system and the concentrations of the materials entering and leaving the system must be estimated. A portable $10 \mathrm{~m}$ long plexiglas tunnel (Benthic Ecosystem Tunnel - BEST) 
was used to quantify the flux of materials and water across the system. The tunnel is composed of 8 sections which cover $7.9 \mathrm{~m}^{2}$ and retains a non-flow volume of $1.74 \mathrm{~m}^{3}$. The individual sections were joined by rubber gaskets and rubber skirts on the edges of the tunnel prevented leakage between tunnel and sediments.

The soft body biomass of the oysters within the tunnel area was determined non-destructively by measuring the height of all oysters in eight $1 / 16 \mathrm{~m}^{2}$ quadrats at the beginning of the study. Height measurements were converted to dry soft body biomass using the relationship derived by Dame (1972a). Utilizing this method, integrated dry soft body biomass was $196 \mathrm{~g} \mathrm{~m}^{-2}$. Dame (1979) described the reef macrofaunal community; oysters account for about $92 \%$ of the dry body biomass.

At each sampling the tunnel was deployed in the exact same location at low tide and removed at the next low tide. Water velocities were measured with a Marsh/McBirney $201 \mathrm{M}$ flow meter mounted in the central section of the tunnel. Discrete $500 \mathrm{ml}$ water samples for material concentration determinations were pumped simultaneously from $0.5 \mathrm{~m}$ inside each end of the tunnel 12 times over a tidal cycle (time the reef was submerged). An effort was made to distribute sampling intervals equally over flood and ebb tide phases. Sampling took place approximately every 10.2 d from June 1983 to June 1984. Samples were analyzed for particulate organic carbon (POC), dissolved organic carbon (DOC), total nitrogen (TN), total dissolved nitrogen (TDN), nitrite + nitrate (NN), ammonium $\left(\mathrm{NH}_{4}\right)$, total phosphorus (TP), total dissolved phosphorus (TDP), and orthophosphate $\left(\mathrm{PO}_{4}\right)$ following the methods described by Dame et al. (1984).

As there was continuity of water flow through the tunnel, water flux (discharge) was estimated from the calibrated velocity measurements. The difference in material concentrations between input and output ends of the tunnel was multiplied by water discharge to yield instantaneous net mass transport. The influence of water column processes was assumed to be unimportant because (1) the water within the tunnel and the creek was well mixed and the same processes should be occurring simultaneously at both the input and output ends of the tunnel and (2) the length of time the water was within the tunnel ( 0.5 to $6 \mathrm{~min}$ ) was insufficient to produce measurable changes in material concentrations (R. Zingmark unpubl.). Total net transport for flooding tides was estimated by averaging the 6 instantaneous net mass transport values for the flood tide and multiplying by $(\mathrm{A}+\mathrm{B})$, where $\mathrm{A}$ was the length of time during the flood tide that the tunnel was completely submerged and $\mathrm{B}$ was $1 / 2$ the time between the onset of water at the input end of the tunnel and full tunnel submergence (time oysters were submerged). This estimation procedure was selected after observing no noticeable trend in instantaneous net mass transport over individual flood or ebb tides. Similarly, net ebb tide transport was determined by averaging the 6 instantaneous net mass transport estimates and multiplying by $(C+D)$, where $C$ was the length of time during the ebb tide that the tunnel was submerged and D was $1 / 2$ the time between when the tunnel was last fully submerged and all water had left the tunnel. If the net mass transport had a positive value, material uptake occurred as the water passed through the tunnel. If the net mass transport had a negative value, material was released.

A paired $t$-test was used on the set of 6 instantaneous net mass transport observations ( 6 for flood and 6 for ebb) to determine if the total net transport for an individual flood or ebb tide was statistically significantly different from zero. Since the water entering the tunnel had not been within the chamber, this water was a control or untreated sample, while the water leaving the tunnel was an experimental or treated sample. It was assumed that the presence of the tunnel had no effect on the biogeochemistry of the sampling site, although the tunnel may reduce water velocities as much as $20 \%$ (B. Kjerfve unpubl.) and lead to a possible overestimation of particulate uptake (Dame 1987).

The design of this study was such that the statistical technique of regression estimation could be used to estimate net annual flux of a given constituent. Cochran (1977, p. 189-200) and Spurrier \& Kjerfve (1988) provide a discussion of regression estimation. There were a total of 707 tidal cycles during the year-long sampling period. Net transport was estimated from observed data for a systematic sample of 33 of the population of 707 cycles or one tidal cycle every $10.2 \mathrm{~d}$. In order to estimate net transport on each tidal cycle during the year, a set of 24 potential predictor variables were measured for each of the 707 total cycles of which 20 were used to predict the material fluxes of carbon, nitrogen and phosphorus (Table 1). Because there were $2^{24}$ subsets of predictor variables to consider, stepwise regression was performed first, in order to reduce the number of subsets considered. Then this smaller set of predictor variables was further refined by running all possible regressions and selecting the model that produced the minimum value of the Mallows (1973) $C P$ statistic. The regression estimate of net annual flux is equal to the sum of the predicted flux values for the 707 tidal cycles.

The purpose of the regression model is to provide the best estimate of the annual flux of a constituent. This method has a smaller standard error than the traditional method of averaging individual tidal cycle estimates and multiplying by the total number of tidal cycles. The variability that regression estimation explains reduces the standard error of the estimate of 
Table 1 Variables considered as 'predictor variables and used in regression estimates to pruduce annual flux budgets

\begin{tabular}{|ll|}
\hline Variable name & Description \\
\hline AWTMP & Water temperature $-18.47^{\circ} \mathrm{C}^{\circ}$ \\
WTMP2 & Square of water temperature \\
AIRWTR & Air temperature - water temperature \\
TIDE & Maximum water column depth \\
L1TIDE & Maximum water column depth on previous cycle \\
L2TIDE & Maximum water column depth on second previous tide \\
RAIN & Rainfall on current cycle \\
L1RAIN & Rainfall on previous cycle \\
L2RAIN & Rainfall on second previous cycle \\
R13 & Sum of rainfall exceeding 1.27 cm over preceding 8 cycles \\
R14 & Sum of rainfall exceeding 0.25 cm over preceding 8 cycles \\
FRESHWATER & Freshwater flow during current cycle \\
L2FRESH & Freshwater flow during second previous cycle \\
AWIND & Average wind speed $-8.76^{b}$ \\
MXWIND & Maximum wind speed \\
AWNDWT & AWIND $\times$ AWTMP \\
LIGHT & Proportion of tidal cycle in daylight \\
ALTWT & AWTMP $\times$ (LIGHT -0.5$)^{c}$ \\
BIO & Biomass of live creekside Spartina alterniflora \\
DERBIO & Derivative of BIO with respect to time \\
& \\
a $18.47{ }^{\circ} \mathrm{C}=$ average of water temperatures for sampled cycles \\
$8.76=$ average of average wind speeds for sampled cycles in mph \\
$($ LIGHT -0.5$)=$ average of the variable LIGHT for sampled cycles \\
\hline
\end{tabular}

annual flux. The standard error associated with the annual net flux estimate took into account cycle-tocycle variability in net tidal cycle flux as well as error in estimating actual net flux for the 33 sampled cycles. It is important to stress that the purpose of the regression models was to efficiently estimate annual net flux. These models should not be used to draw conclusions about mechanistic causes and effects within the estuary. While issues of cause and effect are of great scientific interest, it would take many more observed cycles to attempt to do this.

\section{RESULTS AND DISCUSSION}

\section{Carbon}

POC was taken up by the oyster reef on $95 \%$ of the observed flooding tides and released on $63 \%$ of the ebbing tides (Table 2). The observed fluxes of POC were probably the net result of biofiltration by the organisms on the oyster reef and the physical processes of sedimentation and resuspension. Oysters can filier particles larger than $1 \mu \mathrm{m}$ from suspension although the efficiency of filtration is reduced by $2 / 3$ for particles between 1 and $3 \mu \mathrm{m}$ (Haven \& Morales-Alamo 1970). In our study, the mean uptake rate of POC on flood tides was $1.87 \mathrm{~g} \mathrm{C} \mathrm{m}^{-2} \mathrm{~h}^{-1}$ which was considerably higher than the filtration rate of $0.34 \mathrm{~g} \mathrm{C} \mathrm{m}^{-2} \mathrm{~h}^{-1}$ indirectly estimated from literature values for an annual temperature of $20^{\circ} \mathrm{C}$ by Dame \& Patten (1981). This observation suggests that some other process such as physical sedimentation may be important on the reef. In a separate analysis, Dame et al. (1985) found that most uptake of particulate material on the oyster reef took place at velocities below $15 \mathrm{~cm} \mathrm{~s}^{-1}$, but at velocities above $15 \mathrm{~cm} \mathrm{~s}^{-1}$ release of particulates dominated. This velocity, $15 \mathrm{~cm} \mathrm{~s}^{-1}$, is the approximate minimum velocity for resuspension of creek sediments in North Inlet (Palmer

Table 2. Direction of carbon, nitrogen and phosphorus net fluxes on 33 observed tidal cycles. Numbers in parenthesis indicate values significant at the 0.05 leve]

\begin{tabular}{|llccc|}
\hline Constituent & \multicolumn{2}{c}{ Flood } & \multicolumn{2}{c}{ Ebb } \\
& Uptake & Release & Uptake & Release \\
\hline DOC & 13 & $20(1)$ & 12 & $21(1)$ \\
$\mathrm{POC}$ & $31(14)$ & 2 & $12(2)$ & $21(1)$ \\
$\mathrm{TOC}$ & $25(5)$ & 8 & $11(1)$ & $22(1)$ \\
$\mathrm{TDN}$ & 13 & 20 & $18(1)$ & $15(1)$ \\
$\mathrm{NH}_{4}$ & 10 & $23(5)$ & 9 & $24(3)$ \\
$\mathrm{NN}$ & 12 & $21(2)$ & 16 & $17(1)$ \\
$\mathrm{DON}$ & $15(1)$ & 18 & 19 & 14 \\
$\mathrm{PN}$ & $25(4)$ & 8 & $13(1)$ & -20 \\
$\mathrm{TN}$ & $27(5)$ & 6 & $15(2)$ & 18 \\
$\mathrm{PO}$ & 17 & $16(3)$ & 10 & $23(4)$ \\
$\mathrm{PP}$ & $29(12)$ & 4 & 12 & 21 \\
$\mathrm{TP}$ & $30(16)$ & 3 & $11(2)$ & $22(1)$ \\
\hline
\end{tabular}




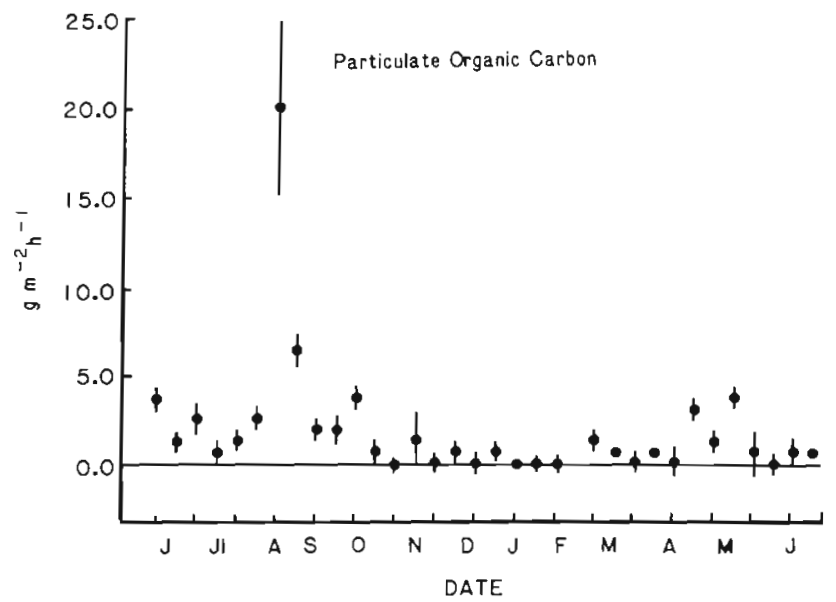

Fig. 1. Observed annual uptake and release of particulate organic carbon by the intertidal oyster reef on flood tides. Vertical bars: 1 standard error

pers. comm.), and is the threshold velocity for turbulent mixing over the oyster reef (Kjerfve unpubl.). Thus on ebbing tides, particulate material accumulated by earlier sedimentation is probably resuspended as a result of higher water velocities. Besides tidal variations in POC fluxes, there were seasonal variations. With maximum rates of uptake in the spring-summer-fall period
(Fig. 1) when particulate concentrations in the water column are normally higher (Wolaver et al. 1986) and when the metabolic rates of estuarine organisms, such as oysters, are at a maximum (Dame 1972b).

As with POC, several different processes result in the uptake and release of DOC by the oyster reef. The intertidal oyster reef released DOC on ca $63 \%$ of the flooding and ebbing tides (Table 2). There was an estimated average release of DOC by the oyster reef of $0.04 \mathrm{~g} \mathrm{C} \mathrm{m}^{-2} \mathrm{~h}^{-1}$ on the flooding tides and $0.33 \mathrm{~g} \mathrm{C} \mathrm{m}^{-2}$ $\mathrm{h}^{-1}$ on the ebbing tides. Oysters have been shown to excrete the organic compounds of urea, amino acids, and uric acid (Hammen et al. 1966, Hammen 1968). In addition, the magnitude of these losses is thought to increase considerably during exposure to rapidly reduced salinity (Bayne 1976). In this study, there were no rapid changes in salinity over any observed tidal cycles, even though salinities were seasonally lower from January to May (15 to $25 \mathrm{ppt}$ ) as compared with the rest of the year when salinities were near oceanic (34 to 36 ppt). However, there were no corresponding seasonal changes in DOC release rates. Alternatively, Manahan et al. (1982), Stephens (1982) and Wright (1982) have provided evidence that bivalve filter feeders remove free amino acids from solution in quantities which may supply significant portions of the nutritional

Table 3. Coefficient of determination, significance level and predictor variables used in the annual regression estimates for a given constituent flux by the oyster reef. Independent variables are as explained in Table 1 and dependent variables are material constituents defined in test. - Regression estimate significant at $5 \%$ level. E (ebb) or F (flood): predictor variable used in final regression estimate for a given phase of the tide

\begin{tabular}{|c|c|c|c|c|c|c|c|c|c|c|c|c|}
\hline Constituent: & DOC & POC & TOC & TDN & $\mathrm{NH}_{4}$ & NN & DON & PN & TN & $\mathrm{PO}_{4}$ & PP & $\mathrm{TP}$ \\
\hline $\begin{array}{l}\text { Flood } r^{2} \\
\text { Significance }\end{array}$ & 0.04 & 0.56 & 0.34 & 0.61 & 0.67 & 0.35 & 0.51 & 0.22 & 0.54 & 0.19 & 0.25 & $\stackrel{0.43}{\cdot}$ \\
\hline AWTMP & & & & $E$ & $\mathrm{E}$ & & & & & & & \\
\hline WTMP2 & & & & FE & & & $F E$ & & & & & \\
\hline AIRWTR & & & & $F$ & & $F$ & $F$ & & & & & \\
\hline TIDE & & $\mathrm{F}$ & & $\mathrm{F}$ & & & $F$ & FE & & & & \\
\hline L1TIDE & E & & $E$ & & & & & & & F & $\mathrm{F}$ & \\
\hline L2TIDE & & & & $\mathrm{F}$ & & & F & & & & FE & $\mathrm{FE}$ \\
\hline RAIN & & $\mathrm{F}$ & $\mathrm{F}$ & & & $E$ & & & & & & \\
\hline L1RAIN & $\mathrm{F}$ & $\mathrm{FE}$ & $\mathrm{F}$ & & & $\mathrm{F}$ & & F & & & & E \\
\hline L2RAIN & $\mathrm{E}$ & & FE & & & FE & & F & E & & & $\mathrm{F}$ \\
\hline R13 & & $\mathrm{F}$ & $\mathrm{F}$ & & $F$ & $E$ & $E$ & & & $\mathrm{~F}$ & & \\
\hline R14 & & $E$ & & $\mathrm{E}$ & & & & & $\mathrm{F}$ & & & \\
\hline FRESHWATER & & & & & & & & & $\mathrm{F}$ & & & \\
\hline L2FRESH & & & & F & & $\mathrm{F}$ & F & & & & & \\
\hline AWIND & & & & & & & & & $F$ & & & \\
\hline MXWIND & & & & & $F$ & & & $\mathrm{FE}$ & $\mathrm{E}$ & & & \\
\hline AWNDWT & & & & & & & & & $E$ & & & \\
\hline LIGHT & & & & & $F$ & & & & & & & \\
\hline A.ITINT $\ldots$ & & & & $F$ & & & & & $\mathrm{~F}$ & & & $F$ \\
\hline $\begin{array}{l}\text { BIO } \\
\text { DERBIO }\end{array}$ & & FE & & & $F E$ & & & $\mathrm{~F}$ & & & & \\
\hline $\begin{array}{l}\text { Ebb } r^{2} \\
\text { Significance }\end{array}$ & 0.38 & 0.39 & 0.41 & 0.49 & 0.30 & 0.15 & 0.13 & 0.16 & 0.18 & 0.12 & 0.09 & $\begin{array}{c}0.49 \\
.\end{array}$ \\
\hline
\end{tabular}


Table 4. Yearly carbon budget for the intertidal oyster reef in $\mathrm{g} C \mathrm{~m}^{-2} \mathrm{yr}^{-1}$ (with standard error)

\begin{tabular}{|c|c|c|c|}
\hline $\begin{array}{l}\text { Consti- } \\
\text { tuent }\end{array}$ & Flood & Ebb & Net \\
\hline$D O C$ & $-22 \quad(683)$ & $-2567^{\circ}(874)$ & $-2589^{\circ}(1103)$ \\
\hline POC & $4704^{\bullet}(1706)$ & $-1286 \quad(849)$ & 3418 (1906) \\
\hline TOC & $5389^{\circ}(2174)$ & $-4189 \cdot(1025)$ & $1200 \quad(2400)$ \\
\hline \multicolumn{4}{|c|}{$\begin{array}{l}\text { Model significant at } 5 \% \text { level } \\
+ \text { : uptake (no sign indicated) } \\
\text {-: release }\end{array}$} \\
\hline
\end{tabular}

needs of these organisms. In addition, other organisms common to the oyster reef, such as bacteria, microbenthic algae and macrobenthic algae, are known to take up and release DOC in the marine environment (Valiela 1984). Finally, increased water velocities may increase the release of DOC from benthic systems (Boynton et al. 1981).

Regression estimation was used to estimate the annual carbon fluxes. The regression models always incorporated some variable for rain and the POC and TOC models have the highest coefficients of determination (Table 3). Yearly estimates of carbon fluxes (Table 4) yielded significant uptakes of POC and TOC on the flooding tides and significant releases of DOC and TOC on the ebbing tides. There is a significant annual release of DOC and a possible uptake of POC. The estimate of net TOC uptake was $1200 \mathrm{~g} \mathrm{C} \mathrm{m}^{-2} \mathrm{yr}^{-1}$ by the oyster reef, but was not statistically different from zero.

\section{Nitrogen}

The flux patterns of TN and particulate nitrogen (PN) were similar to TOC and POC with uptakes dominating on flooding tides and releases occurring on the majority of ebbing tides (Table 2). Dissolved nitrogen constituents were both taken up and released by the oyster reef. Only $\mathrm{NH}_{4}$ showed a consistent pattern of release on both flooding and ebbing tides (Table 2). Oysters Crassostrea virginica are mainly excretors of ammonia and also excrete small amounts of urea and amino acids (Hammen et al. 1966, Srna \& Baggaley 1976). In addition, bacteria in the sediment may also release $\mathrm{NH}_{4}$ as a result of decomposition (Valiela 1984). The $\mathrm{NH}_{4}$ fluxes on the flooding tides showed a seasonal pattern of uptake during the late winter and early spring and release during the remainder of the year (Fig. 2). We interpret this behavior to be the result of $\mathrm{NH}_{4}$ uptake by macroalgae attached to oyster shells which flourish during the winter and reduced net $\mathrm{NH}_{4}$ production by the reef in the colder conditions of winter. Besides $\mathrm{NH}_{4}$

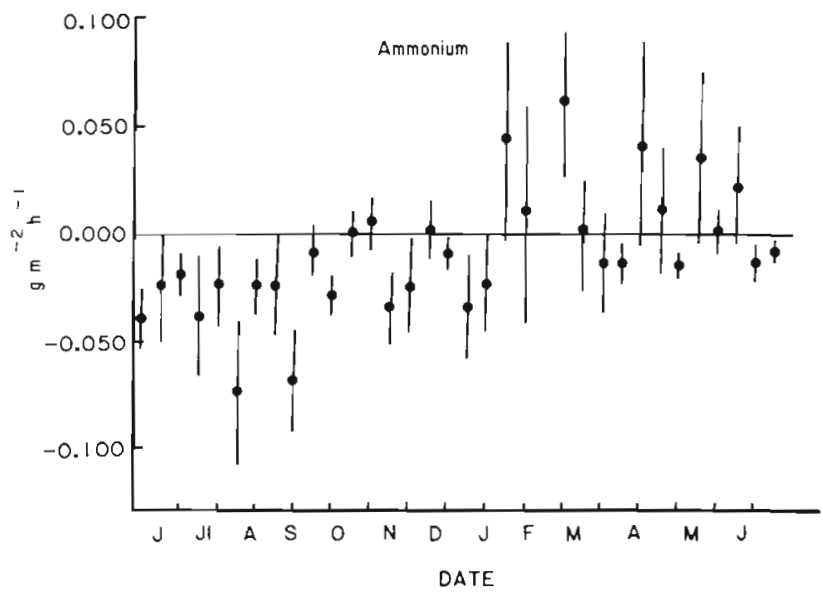

Fig. 2. Observed annual uptake and release of ammonium by the intertidal oyster reef on flood tides. Vertical bars: 1 standard error

releases, physiological studies of oysters have shown that these animals are capable of actively taking up free amino acids (Manahan et al. 1982, Stephens 1982, Wright 1982) and excreting amino acids and urea (Hammen et al. 1966, Hammen 1968).

The regression estimates for the annual fluxes of nitrogen (Table 3) yielded significant PN net uptake on flooding tides and a non-significant net release on ebbing tides (Table 5). There was a significant release of $\mathrm{NH}_{4}$ on flood and ebb tides, while there was a significant release of DON on flood tides and a significant uptake on ebb tides. There was a significant release of TDN on flood tides and a non-significant uptake on ebb tides. There was an estimated net uptake of $189 \mathrm{~g} \mathrm{~N} \mathrm{~m}^{-2} \mathrm{yr}^{-1}$ by the oyster reef, but this value is not significantly different from zero.

Of the amount of nitrogen estimated to be taken up by the oyster reef as $\mathrm{TN}, \mathrm{NH}_{4}$ release accounts for $66 \%$, a value similar to the $55 \% \mathrm{NH}_{4}$ release of $\mathrm{PN}$ absorbed by the marsh mussel Geukensia demissa in a New England salt marsh (Jordan \& Valiela 1982). The

Table 5. Yearly nitrogen budget for the intertidal oyster reef in $\mathrm{g} \mathrm{N} \mathrm{m}{ }^{-2} \mathrm{yr}^{-1}$ (with standard error)

\begin{tabular}{|lrrrrrr|}
\hline Constituent & \multicolumn{2}{c}{ Flood } & \multicolumn{2}{c}{ Ebb } & \multicolumn{2}{c|}{ Net } \\
\hline TDN & $-116^{\circ}$ & $(39)$ & 91 & $(63)$ & -25 & $(111)$ \\
$\mathrm{NH}_{4}$ & $-58^{\circ}$ & $(12)$ & $-67^{\circ}$ & $(20)$ & $-125^{\circ}$ & $(24)$ \\
$\mathrm{NN}$ & 0.3 & $(1.9)$ & -1.3 & $(2.5)$ & -1.0 & $(3.4)$ \\
$\mathrm{DON}$ & $-136^{\circ}$ & $(55)$ & $263^{\circ}$ & $(81)$ & 127 & $(99)$ \\
$\mathrm{PN}$ & $472^{\circ}$ & $(126)$ & -250 & $(154)$ & 222 & $(198)$ \\
$\mathrm{TN}$ & $275^{\circ}$ & $(108)$ & -86 & $(80)$ & 189 & $(134)$ \\
- Model significant at 5\% level & & & \\
+: uptake (no sign indicated) \\
-: release
\end{tabular}


summer flux of $\mathrm{NH}_{4}$ from the oyster reef averages $5500 \mu \mathrm{g}$-at. $\mathrm{m}^{-2} \mathrm{~h}^{-1}$ which is close to the average release rates of $\mathrm{NH}_{4}$ of $5000 \mu \mathrm{g}$-at. $\mathrm{m}^{-2} \mathrm{~h}^{-1}$ reported by Nixon et al. (1976) for a Mytilus edulis bed in Rhode Island.

Using Srna \& Baggaley's (1976) observed rates of $\mathrm{NH}_{4}$ release by individual oysters $\left(250 \mu \mathrm{g} \mathrm{N} \mathrm{g} \mathrm{d}^{-1}\right)$ and knowing the soft body dry weight biomass of oysters on our reef $\left(196 \mathrm{~g} \mathrm{~m}^{-2}\right)$, we can calculate a scaled-up estimate of $\mathrm{NH}_{4}$ release by the oysters on the reef of $17.8 \mathrm{~g} \mathrm{~N} \mathrm{~m}^{-2} \mathrm{yr}^{-1}$. As with the scaled-up carbon uptake values presented earlier, the organismic estimates are about an order of magnitude lower than those observed for the reef system. Boucher \& Boucher-Rodoni's (1988) dome studies of nitrogen fluxes at the interface of an artificial oyster bed found that oysters only accounted for $40 \%$ of the nitrogen release and the rest was attributed to the sediments. Their results support our findings.

Zooplankton have the potential to excrete large amounts of nutrients (Mann 1982), but in southeastern U.S. estuaries the standing crop of zooplankton is sometimes low enough to reduce their importance (Williams et al. 1968). In North Inlet, zooplankton biomass averages $16.2 \mu \mathrm{g} \mathrm{m} \mathrm{m}^{-3}$ (Lonsdale \& Coull 1977) and assuming a nitrogen excretion rate of $10 \mu \mathrm{g} \mathrm{N} \mathrm{mg}{ }^{-1} \mathrm{~d}^{-1}$ (Mann 1982), then $59.1 \mu \mathrm{g} \mathrm{N} \mathrm{m}{ }^{-3}$ would be excreted annually. Bly Creek has an average volume of $1.9 \times 10^{5}$ $\mathrm{m}^{3}$ which when multiplied by the annual zooplankton excretion rate yields a total nitrogen excretion of $11.2 \mathrm{~g}$ $\mathrm{N} \mathrm{yr}^{-1}$. This amount is less than the annual flux of $1 / 10 \mathrm{~m}^{2}$ of oyster reef, i.e. $125 \mathrm{~g} \mathrm{~N} \mathrm{~m}^{-2}$ (Table 5).

We have suggested (Dame et al. 1985) that the oyster reef may be part of a positive feedback loop in which particulate nitrogen (phytoplankton) consumed by the oyster reef is rapidly remineralized to $\mathrm{NH}_{4}$. The $\mathrm{NH}_{4}$ is then available as a nutrient for additional plant growth. This feedback loop may be viewed both as a nitrogen

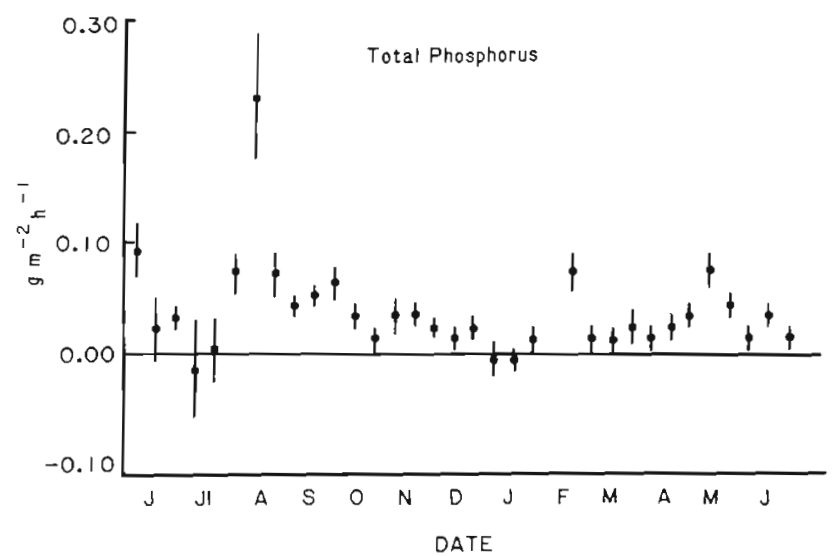

Fig. 3. Observed annual uptake and release of total phosphorus by the intertidal oyster reef on flood tides. Vertical bars: 1 standard error retention mechanism and a process which drives the nitrogen cycle at a higher cycle rate.

\section{Phosphorus}

The phosphorus constituents exhibited patterns of uptake and release similar to carbon and nitrogen. TP and PP were apparently taken up respectively on $91 \%$ and $87 \%$ of the flooding tides with release apparently dominating by a 2 to 1 margin on the ebbing tides (Table 2). The phosphorus constituents exhibited higher flux rates in spring, summer and fall (Fig. 3) and minimum rates in winter.

The regression estimations for annual phosphorus fluxes are from the models described in Table 3. From these estimations, there was phosphorus uptake on flooding tides and release on ebbing tides. There was a statistically significant net uptake of $98 \mathrm{~g} \mathrm{P} \mathrm{m}^{-2} \mathrm{yr}^{-1}$ for the oyster reef (Table 6).

Bivalve filter feeders seem to move much more phosphorus to the sediments than they remineralize in metabolism. Our oyster reef released $8 \%$ of the yearly TP uptake as $\mathrm{PO}_{4}$. Recent studies on phosphorus uptake by a low density (200 ind. $\mathrm{m}^{-2}$ ) oyster reef in France dominated by Crassostrea gigas also showed that only a small amount ( $3 \%$ ) of the TP filtered was absorbed by the oysters with the remaining forming biodeposits (Sornin et al. 1986). In the French system, the oysters accounted for $47 \%$ of the total phosphorus deposited by all means.

\section{Carbon: nitrogen : phosphorus}

The ratios of the fluxes of total carbon, total nitrogen and total phosphorus into the oyster reef is ca $12.2: 1.9: 1$. These ratios are considerably different from the ratios for general oceanographic material of 108:15.5:1 (Redfield et al. 1963). However, the C:N ratio is 6.4 for the oyster reef fluxes and about 7 for general material. Several studies (Newell 1982, Vink \&

Table 6. Yearly phosphorus budget for the intertidal oyster reef in $\mathrm{g} \mathrm{P} \mathrm{m}{ }^{-2} \mathrm{yr}^{-1}$ (with standard error)

\begin{tabular}{|c|c|c|c|}
\hline Constituent & Flood & Ebb & Net \\
\hline $\mathrm{PO}_{4}$ & $1.4(3.4)$ & $-9.1(4.7)$ & $-7.7(5.8)$ \\
\hline PP & $156^{\circ}$ & $-86 \quad(82)$ & 70 \\
\hline TP & $136^{\circ} \quad(22)$ & $-38^{\circ} \quad(12)$ & $98^{\circ} \quad(25)$ \\
\hline \multicolumn{4}{|c|}{$\begin{array}{l}\text { Model significant at } 5 \% \text { level } \\
+: \text { uptake (no sign indicated) } \\
\text {-: release }\end{array}$} \\
\hline
\end{tabular}


Atkinson 1985) have reported $\mathrm{C}: \mathrm{N}$ ratios for mussel bodies ranging from 3.9 to 6.8 which are similar to the oyster reef input ratios. With an expected Redfield $N: P$ ratio of 16 and an actual uptake $N$ : P ratio of 2 , the oyster reef appears to be taking up proportionally more phosphorus than nitrogen and carbon. Thus this bivalve system seems to remove considerably more phosphorus from estuarine waters than would be expected. Oyster reefs and bivalves may be significant components or mechanisms in retaining phosphorus - a constituent which unlike nitrogen and carbon can only enter the estuary via land runoff or import from the coastal ocean.

\section{CONCLUSION}

Our studies on an intertidal oyster reef show that these systems do process materials at high rates and generally convert particulate materials to dissolved materials. However, there is considerable variation in most material net fluxes and a major portion of this variability seems caused by differences in ebb and flood tidal velocity patterns. The most consistent fluxes are the releases of $\mathrm{NH}_{4}$ and DOC by the oyster reef. Because estuarine systems are generally thought to be nitrogen limited, from the significant $\mathrm{NH}_{4}$ releases by oyster reefs we infer an important functional role in the recycling nitrogen. The importance of any oyster reef's influence on nitrogen cycling will depend on the abundance of oysters, the aerial extent of oyster reefs and the volume of water these systems interact with on a given tidal cycle.

Acknowledgements. We express our gratitude to the other members of the Bly Creek Ecosystem Study team, especially E. Haskin, R. Zingmark, and B. Kjerfve, who helped make this study possible. We also appreciate the assistance of the many undergraduate marine science students from Coastal Carolina College who assisted in the field work. The suggestions and comments of $M$. Crosby were most helpful in producing the manuscript. This project was supported by NSF Grant DEB8119752 and is publication No. 746 of the Belle W. Baruch Institute for Marine Biology and Coastal Research.

\section{LITERATURE CITED}

Bayne, B. L. (ed.). (1976). Marine mussels: their ecology and physiology. Cambridge Univ. Press, New York

Bertness, M. D. (1984). Ribbed mussels and the productivity of Spartina alterniflora in a New England salt marsh. Ecology 65: $1794-1807$

Boucher, G., Boucher-Rodoni, R. (1988). In situ measurement of respiratory metabolism and nitrogen fluxes at the interface of oyster beds. Mar. Ecol. Prog. Ser. 44: 229-238

Boynton, W. R., Kemp, W. M., Osborne, C. G., Kaumeyer, K. R., Jenkins, M. C. (1981). Influence of water circulation rate on in situ measurements of benthic community respiration. Mar. Biol. 65: 185-190
Cloern, J. E. (1982). Does the benthos control phytoplankton biomass in South San Francisco Bay? Mar. Ecol. Prog. Ser 9:191-202

Cochran, W G. (1977). Sampling techniques, 3rd edn. Wiley, New York

Dame, R. F. (1972a). Comparison of various allometric relationships in intertidal and subtidal American oysters. Fish. Bull. U.S. 70: 1121-1126

Dame, R. F. (1972b). The ecological energies of growth, respiration and assimilation in the intertidal American oyster Crassostrea virginica. Mar Biol. 17: 243-250

Dame, R. F. (1987). The net flux of inorganic sediments by an intertidal oyster reef. Cont. Shelf Res. 7: 1421-1424

Dame, R. F., Chrzanowski, T., Bildstein, K., Kjerfve, B., McKellar, H., Nelson, D., Spurrier, J., Stancyk, S., Stevenson, H., Vernberg, J., Zingmark, R. (1986). The outwelling hypothesis and North Inlet, South Carolina. Mar Ecol. Prog. Ser. 33: 217-229

Dame, R. F., Patten, B. C. (1981). Analysis of energy flows in an intertidal oyster reef. Mar. Ecol. Prog. Ser. 5: 115-124

Dame, R. F., Wolaver, T G., Libes, S. M. (1985). The summer uptake and release of nitrogen by an intertidal oyster reef. Neth. J. Sea Res. 19: 265-268

Dame, R. F., Zingmark, R. G., Haskin, E. (1984). Oyster reefs as processors of estuarine materials. J. exp. mar. Biol. Ecol. 83: $239-247$

Dame, R. F., Zingmark, R. G., Stevenson, L. H., Nelson, D. (1980). Filter feeder coupling between the estuarine water column and benthic subsystems. In: Kennedy, V C. (ed.) Estuarine perspectives. Academic Press, New York, p. 521-526

Doering, P. H., Oviatt, C. A., Kelly, J. R. (1986). The effect of the filter feeding clam Mercenaria mercenaria on carbon cycling in experimental mesocosms. J. mar. Res. 44: 839-861

Hammen, C. S. (1968). Aminotransferase activities and amino acid excretion of bivalve molluscs and brachiopods. Comp. Biochem. Physiol. 26: 697-705

Hammen, C. S., Miller, H. F., Geer, W H. (1966). Nitrogen excretion of Crassostrea virginica. Comp. Biochem. Physiol. 17: 1199-1200

Haven, D., Morales-Alamo, R. (1966). Aspects of biodeposition by oysters and other invertebrate filter feeders. Limnol. Oceanogr. 1. $487-498$

Haven, D., Morales-Alamo, R. (1970). Filtration of particles from suspension by the American oyster, Crassostrea virginica. Biol. Bull. mar. biol. Lab., Woods Hole 139: 248-264

Jordan, J. E., Valiela, I. (1982). A nitrogen budget of the ribbed mussel, Geukensia demissa, and its significance to nitrogen flow in a New England salt marsh. Limnol. Oceanogr. 27: 75-90

Kitchell, J., O'Neill, R., Webb, D., Gallepp, G., Bartell, S., Koonce, J., Asmus, B. (1979). Consumer regulation of nutrient cycling. BioSci. 29: 28-34

Kuenzler, E. (1961). Phosphorous budget of a mussel population. Limnol. Oceanogr. 6: 400-415

Lonsdale, D. J., Coull, B. C. (1977). Composition and seasonality of zooplankton of North Inlet, South Carolina. Chesapeake Sci. 18: 272-283

Mallows, C. L. (1973). Some comments on Cp. Technometrics 16: $661-675$

Manahan, D. T., Wright, S. H., Stephens, G. C., Rice, M. A. (1982). Transport of dissolved amino acids by the mussel, Mytilus edulis: demonstration of net uptake from natural seawater. Science 215: 1253-1255

Mann, K. H. (1982). Ecology of coastal waters. Univ. of California Press, Berkley 
Murphy, R. C., Kremer, J. N. (1985). Bivalve contribution to benthic metabolism in a California lagoon. Estuaries 8: 330-341

Newell, R. I. E. (1982). An evaluation of the wet oxidation technique for use in determining the energy content of seston samples. Can. J. Fish. Aquat. Sci. 39: 1383-1388

Nichols, F. (1985). Increased benthic grazing: an alternative explanation for low phytoplankton biomass in Northern San Francisco Bay during the 1976-1977 drought. Estuar. coast. Shelf Sci. 21: 379-388

Nixon, S. W., Oviatt, C. A., Garber, J., Lee, V. (1976). Diel metabolism and nutrient dynamics of a salt marsh embayment. Ecology 57: 740-750

Officer, C. B., Smayda, T J., Mann, R. (1982). Benthic filter feeding a natural eutrophication control. Mar. Ecol. Prog. Sci. 9: 203-210

Redfield, A. C., Ketchum, P. H., Richards, F. A. (1963). The influence of organisms on the composition of seawater. In: Hill, M. N. (ed.) The sea, Vol. II, Wiley, London, p. 26-77

Sornin, J.-M., Feuillet, M., Heral, M., Fardeau, J.-C. (1986). Influence des cultures d'huitres Crassostrea gigas sur le cycle du phosphore en zone intertidale: role de la biodeposition. Oceanologica Acta 9: 313-322

Spurrier, J. D., Kjerfve, B. (1988). Estimating the net flux of nutrients between a salt marsh and a tidal creek. Estuaries 11: $10-14$

This article was submitted to the editor
Srna, R. F., Baggaley, A. (1976). Rate of excretion of ammonia by the hard clam Mercenaria mercenaria and the American oyster Crassostrea virginica. Mar. Biol. 36: 251-268

Stephens, G. C. (1982). Recent progress in the study of 'Die Ernährung der Wassertiere und der Stoffhaushalt der Gewässer' Am. Zool. 22: 611-619

Valiela, 1. (1984). Marine ecological processes. SpringerVerlag, New York

Verwey, J. (1952). On the ecology and distribution of cockel and mussel in the Dutch Wadden Sea, their role in sedimentation and the source of their food supply. Archs neerl. Zool. 10: 172-239

Vink, S., Atkinson, M. J. (1985). High dissolved C: P excretion ratios for large benthic marine invertebrates. Mar. Ecol. Prog. Ser 21. 191-195

Wolaver, T G., Hutchinson, S., Marozas, M. (1986). Dissolved and particulate carbon in the North Inlet Estuary - what controls their concentrations. Estuaries 9: 31-38

Wright, R. T., Coffin, R. B., Ersing, C. P., Pearson, D. (1982) Field and laboratory measurements of bivalve filtration of natural marine bacterioplankton. Limnol. Oceanogr 27 : $91-98$

Wright, S. H. (1982). A nutritional role for amino acid transport in filter feeding marine invertebrates. Am. Zool. 22: $621-634$

Manuscript first received: August 2, 1988

Revised version accepted: March 31,1989 